\title{
Ageing process of cementitious materials: Ion transport and diffusion coefficient
}

\author{
A.Babaahmadi \& L.Tang \\ Chalmers University of Technology, Gothenburg, Sweden
}

Z.Abbas

University of Gothenburg, Gothenburg, Sweden

\begin{abstract}
Risk assessment analysis concerning service life predictions of concrete structures in nuclear waste repositories requires broad knowledge about long-term concrete deterioration processes. It is well known that the degradation process of cementitious materials involves diffusion of internal and external ions, interaction between these ions and re-deposition of the interacted products. However, although diffusion properties play an important role in the deterioration process, there is a lack of reliable data on ion diffusivity in concrete, especially co-existing ions rather than chloride. The aim of this study is to further analyze multicomponent ionic diffusion accompanied with surface complexation and selective adsorption. Natural diffusion cell and field immersion tests are used to analyze transport properties of ions present in groundwater surrounding nuclear waste repositories such as chloride, sodium, lithium and calcium ions, through cement paste. Analytical techniques such as Ion chromatography, potentiometric titration, inductively coupled plasma mass spectrometry and X-Ray fluorescence methods are used. Results indicate that the ionic diffusion coefficients differ between different ions and the higher the concentration of the ions, the lower the diffusion coefficient will be.
\end{abstract}

\section{INTRODUCTION}

Deposition of low and intermediate level radioactive waste (LILW) involves processes lasting up to 100000 years. The main concern is the spread of radioactive ions into the groundwater if these leached from the nuclear waste repositories. As concrete is one of the major building materials used in the construction of nuclear waste repositories, predictions of longevity of the structures is of critical importance to the performance analysis of the repository. Since 1980's service life predictions of concrete structures have been recorded in the literature (Fagerlund 1983, Pommersheim \& Clifton 1985, Clifton 1991), but mainly limited to the durability of concrete infrastructures with a designed service life of some tens and hundreds of years, such as bridges, tunnels and nuclear power plants. When dealing with nuclear waste management the time scale of service-life prediction can be up to a hundred thousand years because of the long half-life of radioactive waste products. However, there exist similarities between the degradation process of various concrete structures, that is, diffusion of internal and external ions through cementitious material. Therefore, ionic transport in cementitious materials is one of the key factors governing the deterioration process of concrete structures.
Due to the worldwide problem of chloride induced corrosion of reinforcement steel, modeling of chloride diffusion processes through concrete has been one of dominant parts of the literature. Tang explained these kinds of differences in his ClinConc model, using the concept of "intrinsic diffusion coefficient" combined with that of chloride binding (adsorption) capacity to model chloride transport in the pore solution of concrete (Tang, 1996a, Tang \& Nilsson 1994-1996). Samson et al. (1999a, 1999b), Truc (2000) and Truc et al. (2000) also considered the effects of coexisting ions and used the theory of multi-species diffusion to model ionic transport in concrete. However, reliable data regarding ion diffusivity through cementitious materials is scare and information regarding coexisting ions, and differences between their diffusion coefficients and ion-ion interactions, is even rarely available.

In this paper natural diffusion cell tests using sodium chloride, lithium chloride and lithium nitrate solutions are carried out in order to study the effects of ion-ion interactions on individual diffusion coefficients. Furthermore, the dependency of diffusion coefficient on ionic concentration is studied. In order to study the diffusive characteristics of ions present in groundwater surrounding the nuclear waste repositories, field immersion test is implemented in contact with groundwater 400 meters deep under the 
ground in Äspö laboratory located in Oskarshamn, Sweden.

\section{MATERIAL AND METHOD}

\subsection{Test specimens}

Swedish structural Portland cement (CEM I 42.5N $\mathrm{BV} / \mathrm{SR} / \mathrm{LA}$ ) was mixed with distilled water at a water-cement ratio of 0.5 . Fresh cement paste was cast in acrylic cylinders of an internal diameter of 50 $\mathrm{mm}$. The two ends of the cylinder were sealed with silicone rubber stops. In order to produce homogenized specimens, the cylinders containing fresh paste were kept rotating longitudinally at a rate of 12-14 rpm for 24 hours. Afterwards, the rubber stops were removed, and the two ends of the cylinder were sealed with plastic tape. Specimens were stored in a plastic box and in order to prevent carbonation of the specimens, the bottom of the plastic box, underneath the specimens, was filled with saturated lime water. Typical chemical composition of cement is listed in Table 1.

Table 1. Chemical characteristics of Swedish CEM I $42.5 \mathrm{~N}$ $\mathrm{BV} / \mathrm{SR} / \mathrm{LA}$

\begin{tabular}{|c|c|}
\hline Chamical formulation & Mass percentage \\
\hline $\mathrm{CaO}$ & 64.0 \\
\hline $\mathrm{SiO}_{2}$ & 22.2 \\
\hline $\mathrm{Al}_{2} \mathrm{O}_{3}$ & 3.6 \\
\hline $\mathrm{Fe}_{2} \mathrm{O}_{3}$ & 4.4 \\
\hline $\mathrm{MgO}$ & 0.94 \\
\hline $\mathrm{Na}_{2} \mathrm{O}$ & 0.07 \\
\hline $\mathrm{K}_{2} \mathrm{O}$ & 0.72 \\
\hline $\mathrm{SO}_{3}$ & 2.2 \\
\hline $\mathrm{Cl}$ & 0.01 \\
\hline
\end{tabular}

\subsection{Diffusion cell test}

Conventionally diffusivity of ions in a porous material is measured using a natural diffusion cell test at a certain gradient of concentration (Page 1983). Within the set-up of natural diffusion cell test, two solution containers (cells) are separated by a $10 \mathrm{~mm}$ thick slice of specimen which was cut from the central portion of the cylindrical paste. The cell filled with a solution containing specific ions of interest is called upstream solution and the other cell, which is free of those ions (usually filled with deionized water), is called downstream cell. Diffusion of the ions of interest would happen from the upstream cell to the downstream cell, through the specimen, due to the concentration gradient between the cells.

As shown in Figure 1, Paste specimens of $\varnothing 50 \times 10$ $\mathrm{mm}$ are assembled in the central part of the silicone rubber tube and are tighten in position with a clamp of stainless steel. Cells made of Plexiglass tube are attached to the ends of the silicone rubber tube using a clamp of stainless steel on each ends of the tube. The upstream cell was filled with $250 \mathrm{ml}$ of a solution containing the ions of interest and the downstream cell was filled with $250 \mathrm{ml}$ of demineralized water. A rubber stop was used to close the cells in order to prevent evaporation and possible carbonation. The downstream solution was replaced by fresh demineralized water at certain intervals ( 3 days as an initial interval and 7 days afterwards, depending on the increase of chloride ions in the downstream solution). Replaced downstream solutions were chemically analyzed in order to plot accumulated chloride content $\left(\mathrm{Q}_{\mathrm{Cl}}\right)$, diffused through the specimen, against time $\left(\mathrm{Q}_{\mathrm{Cl}}-\mathrm{t}\right.$ curve $)$. The experiment is terminated when a linear relationship can be observed from the $\mathrm{Q}_{\mathrm{Cl}}-\mathrm{t}$ curve. In order to study transport properties of chloride, sodium, lithium and calcium, 6 different solutions containing these ions were used:

- $5 \mathrm{~g}, 10 \mathrm{~g}$ and $20 \mathrm{~g} \mathrm{NaCl}$ per liter

- 10 and $20 \mathrm{~g} \mathrm{LiCl}$ per liter

- $10 \mathrm{~g} \mathrm{LiNO}_{3}$ per liter

In this study, 18 sets of diffusion cells were used, with three sets per each solution.

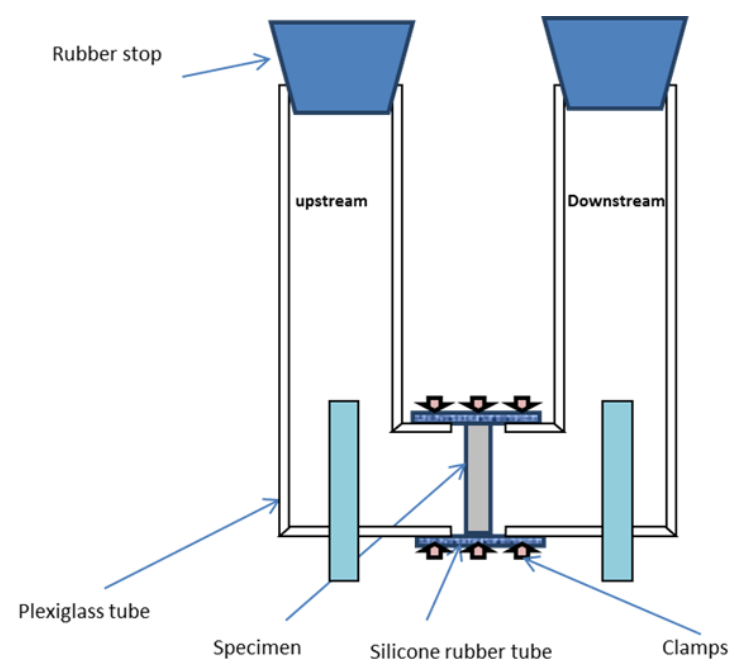

Figure1. Diffusion test set up

Monitoring the concentration changes in the downstream cell and using Flick's first law, the steady state diffusion coefficient is calculated (Crank 1975):

$D_{\text {steady-state }}=\frac{V . \Delta Q}{A \cdot \Delta t} \times \frac{L}{\left(C_{1}-C_{2}\right)}$

Where, $\mathrm{V}$ is the volume of the downstream cell $\left(\mathrm{m}^{3}\right), \Delta Q$ is the increase of the specific ions in the downstream cell $\left(\mathrm{kg} / \mathrm{m}^{3}\right), \Delta t$ is the time interval (s), $A$ is the exposed specimen surface area $\left(\mathrm{m}^{2}\right), \mathrm{L}$ is the exposed slice thickness $(\mathrm{m}), C_{1}$ is the concentration of the specific ions in the upstream solution $\left(\mathrm{kg} / \mathrm{m}^{3}\right)$ 
and $C_{2}$ is the average concentration of specific ions in the upstream solution $\left(\mathrm{kg} / \mathrm{m}^{3}\right)$.

Using the $\mathrm{Q}_{\mathrm{Cl}}-\mathrm{t}$ curve the "time-lag", which is the duration until a significant linear relationship is observed from the $\mathrm{Q}_{\mathrm{Cl}}-\mathrm{t}$ curve, would be specified. The non-steady state diffusion coefficient is calculated from equation 2 (Crank 1975).

$$
D_{\text {non-steady-state }}=\frac{x^{2}}{6 \times t_{n}}
$$

Where, $\mathrm{x}$ is the thickness of the specimen (m) and $t$ is the time-lag (s).

\subsection{Natural immersion test}

The natural immersion test involves immersion of the test specimen in a solution containing specific ions of interest and measuring the penetration depth or penetration profile of these ions in the specimen.

In this study a total of 20 cylinders (10 pastes and 10 mortars) of $\varnothing 46 \times 100-250 \mathrm{~mm}$, cured for 6 months, were coated with thick (3-4 mm) epoxy, sealing all surfaces except one for exposure. The specimens were immersed in ground water 400 meters deep under the ground in the Äspö laboratory located in Oskarshamn, Sweden. Table 2 presents the chemical composition of the groundwater in Äspö lab in 450m deep under the ground and Figure 2 shows the set-up of this experiment in the Äspö lab. After 6 months of exposure, one of the paste samples was chemically analyzed in order to obtain the penetration profile of the specific ions: chloride, sodium, sulfate, calcium, potassium and magnesium through the specimen.

Table 2. Äspö groundwater chemical composition

\begin{tabular}{l|r}
\hline Element & $\begin{array}{l}\text { Content } \\
(\text { mg/lit })\end{array}$ \\
\hline $\mathrm{Na}$ & 1860 \\
$\mathrm{k}$ & 16,9 \\
$\mathrm{Ca}$ & 651 \\
$\mathrm{Mg}$ & 78,2 \\
$\mathrm{HCO}_{3}$ & 130 \\
$\mathrm{Cl}$ & 4080 \\
$\mathrm{SO}_{4}$ & 326 \\
$\mathrm{Br}$ & 19,3 \\
$\mathrm{~F}$ & 1,42 \\
$\mathrm{Si}$ & 8,22 \\
$\mathrm{Fe}$ & 0,522 \\
$\mathrm{Mn}$ & 0,599 \\
$\mathrm{Li}$ & 0,481 \\
\hline
\end{tabular}
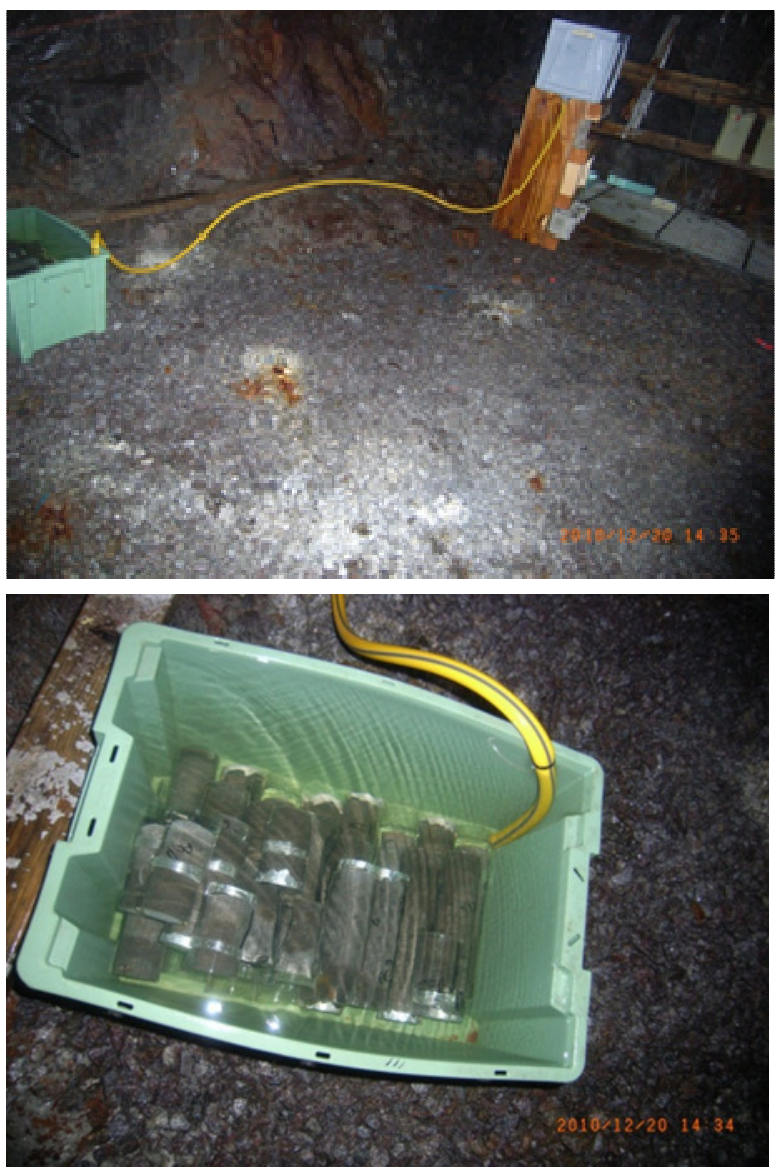

Figure2. Field immersion test set up

Assuming that Flick's second law of diffusion is valid, the non-steady state diffusion coefficient is calculated by fitting the experimental profiles to an error-function of Fick's second law of diffusion for a semi-infinite media (Crank 1975).

$$
C(x, t)=C_{S}\left(1-\operatorname{erf} \frac{x}{2 \cdot \sqrt{D_{\text {non-steady-state }} . t}}\right)
$$

Where, $C_{s}$ is the surface chloride concentration and $C(x, t)$ is the chloride concentrations in respect of position and time.

\subsection{Chemical Analysis}

In order to measure the chloride concentration within the liquid samples gathered from the diffusion cell test, Potentiometric titration method with chloride selective electrode and $\mathrm{AgNO}_{3}(0.01 \mathrm{~N})$ as the titrant, was used. The positive ions ( $\mathrm{Li}, \mathrm{Na}, \mathrm{Ca}$ ) in these samples were analyzed using the ICP-MS (VG Plasma Quad 3, VG Elemental, Winsford, Cheshire, U.K.) system. Qualitative Chemical analysis on the solid samples gathered from the field immersion test was done using LA-ICP-MS and the results concerning chloride and calcium content was calibrated using potentiometric titration of the powder samples. 


\section{RESULT AND DISCUSSION}

The $\mathrm{Q}_{\mathrm{Cl}}-\mathrm{t}$ curves of chloride, lithium and sodium ions are presented in figure 3,4 and 5. The $\mathrm{Q}_{\mathrm{Cl}}-\mathrm{t}$ curve shows the accumulated amount of diffused/leached ions in downstream cell with time and it can be seen that the higher the concentration of the ions in upstream cell, the higher the concentration gradient (slope of the curve) would be.

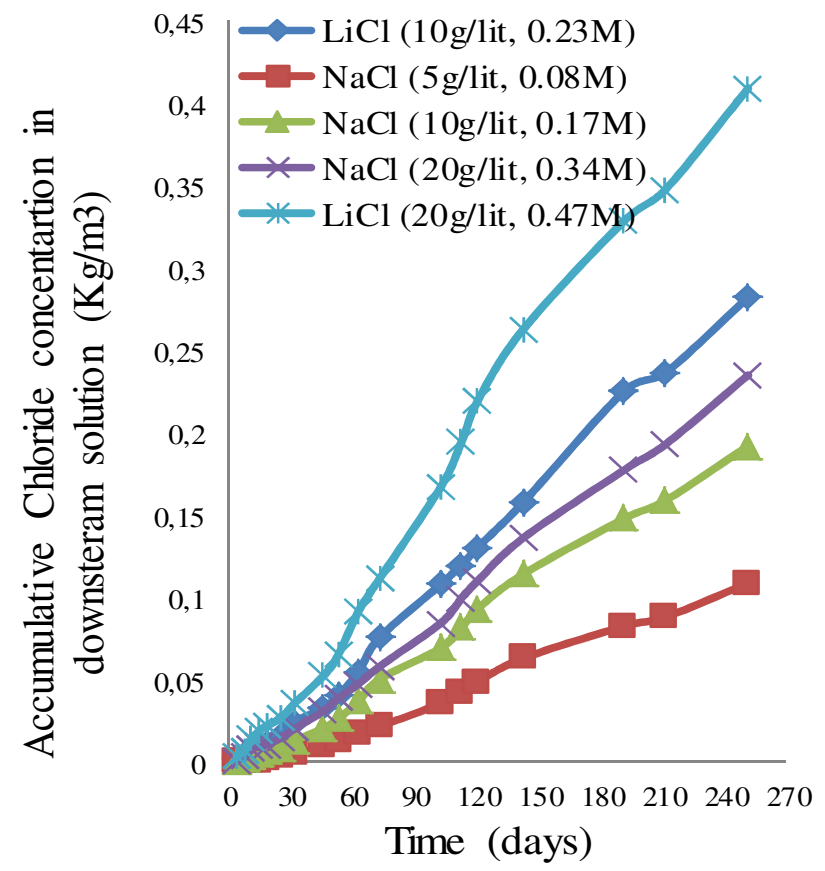

Figur 3. Accumulated chloride content in downstream cell with time

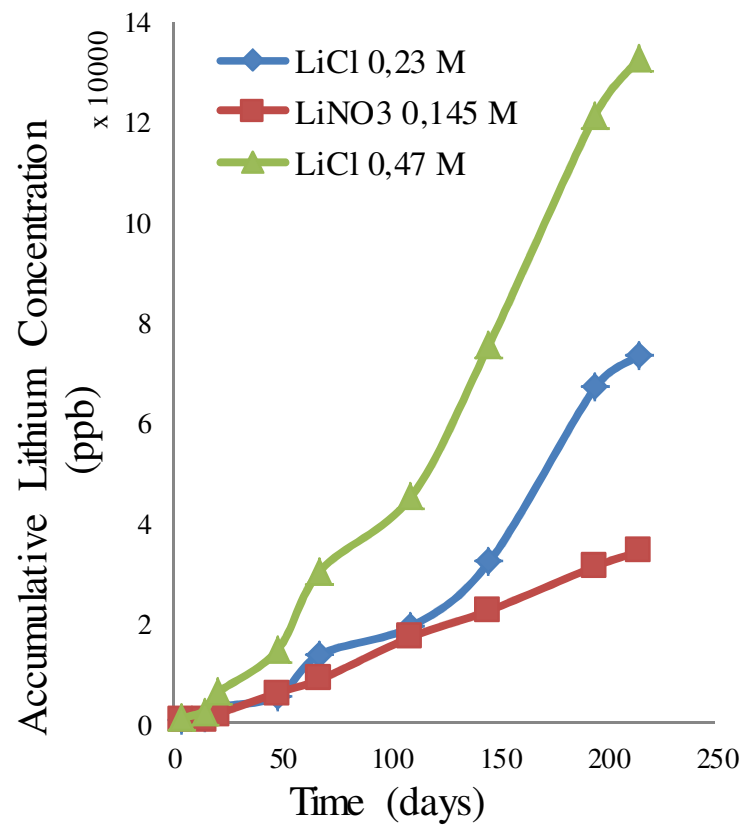

Figur 4. Accumulated lithium content in downstream cell with time

The Steady-State diffusion coefficients of chloride, lithium and sodium ions are presented in figure 6 . The results show that the diffusion coefficient values of cations and anions differ by an order of magnitude. Moreover, the diffusion coefficient val- ues specifically regarding chlorides decreases due to increase in the ionic concentration of upstream cell, which is logical due to the friction effects between ions (Tang 1999). The differences between the cation diffusion coefficients of sodium and lithium can be explained due to their different hydrated ionic size. Lithium ions although smaller than sodium ions in crystalline radius, would carry up a larger water layer around them in solution (Abbas et al. 2009). Consequently larger hydrated ions such as lithium will have a slower movement than sodium ions.

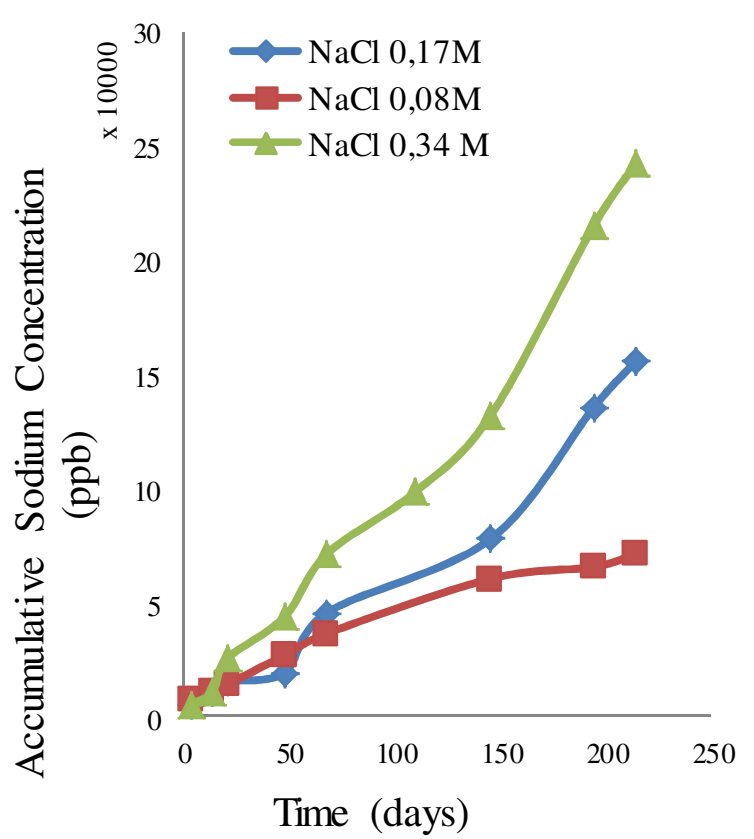

Figur 5. Accumulated sodium content in downstream cell with time

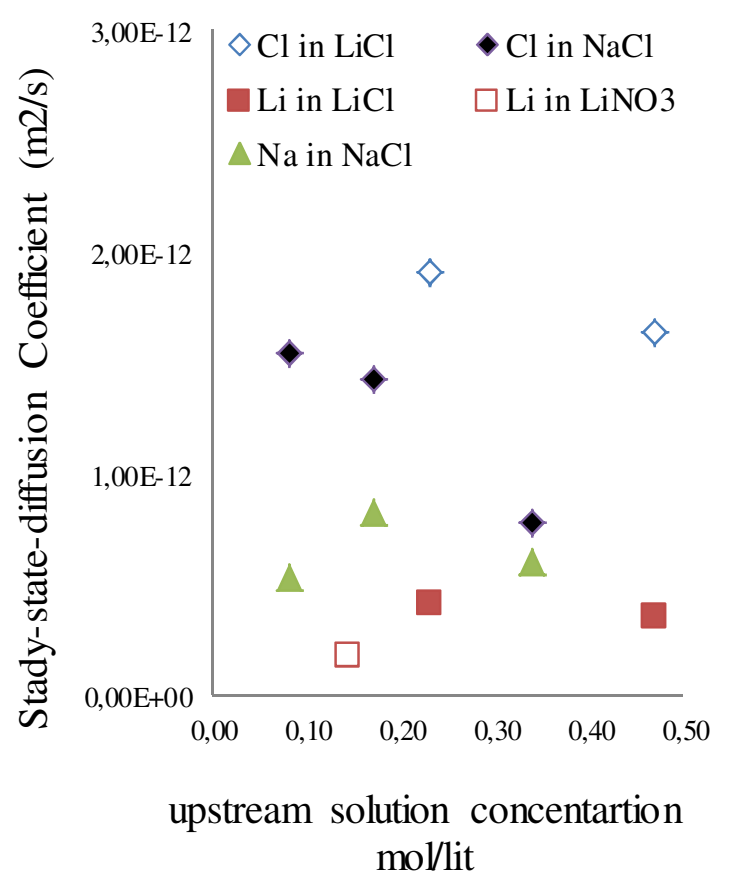

Figure 6. Calculated steady-state diffusion coefficients

Using $\mathrm{Q}_{\mathrm{Cl}}-\mathrm{t}$ curves and the definition of time-lag the non-steady state diffusion coefficients are calculated. The results are presented in figure 7 . It should 
be noted that the estimated values of time-lag can vary slightly as of being dependent on the judgment of the person analyzing the $\mathrm{Q}_{\mathrm{Cl}^{-}} \mathrm{t}$ curve.

The relation between steady and non-steady state diffusion coefficients is logical as the steady state diffusion coefficient is higher than the non-steady state diffusion coefficient, but it should be noted that more study regarding the binding capacity and effective porosity is needed in order to quantify this relation.

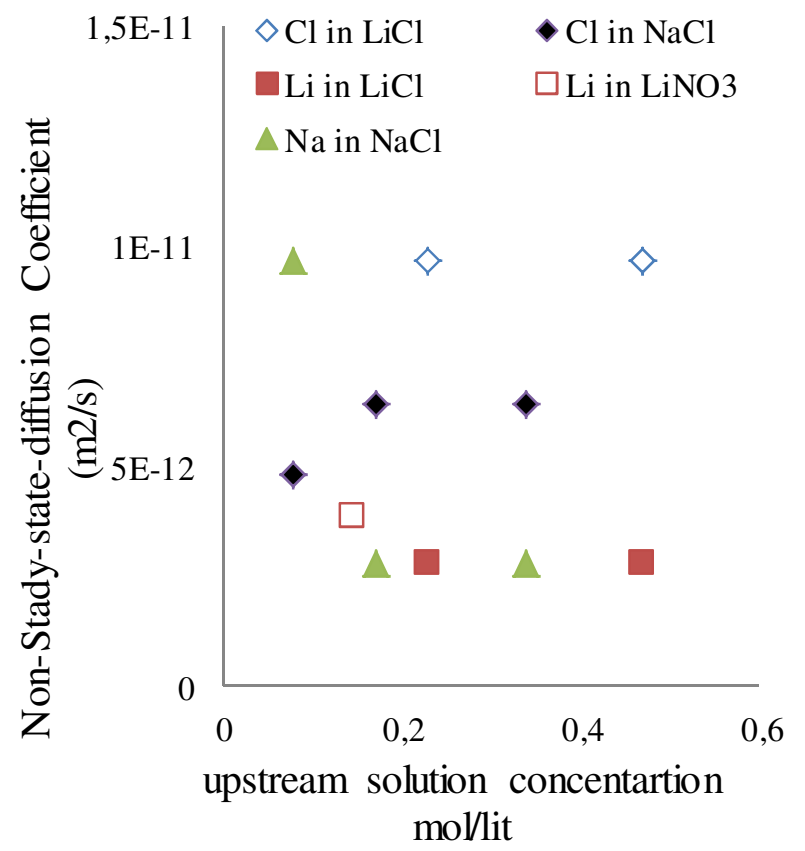

Figure7. Calculated non-steady state diffusion coefficients

The samples from the field immersion test were analyzed qualitatively using LA-ICP-MS. The results are presented in figure 8 . Considering the constituents of Äspö groundwater, presented in table 2, chloride and calcium ions as of having higher concentration in Äspö groundwater, have diffused more than other ions in to the specimen. On the other hand, potassium ions have diffused out from the specimen in to the ground water. The amount of chloride and calcium in the sample is quantified using potentiometric titration and non-steady state diffusion coefficient of chloride is calculated by curve fitting. The results are presented in figure 9 and table 3.

Table 3. non-steady state chloride diffusion parameters

\begin{tabular}{l|l}
\hline \multicolumn{2}{c}{ Curve-fitting results } \\
\hline Surface Cl content $C_{\mathrm{s}}$, mass $\%:$ & 1,712 \\
Transport coefficient $D_{\mathrm{a}}, \mathrm{m}^{2} / \mathrm{s}:$ & $8,86 \mathrm{E}-12$ \\
$R^{2}$ (for selected data): & 0,996 \\
\hline
\end{tabular}

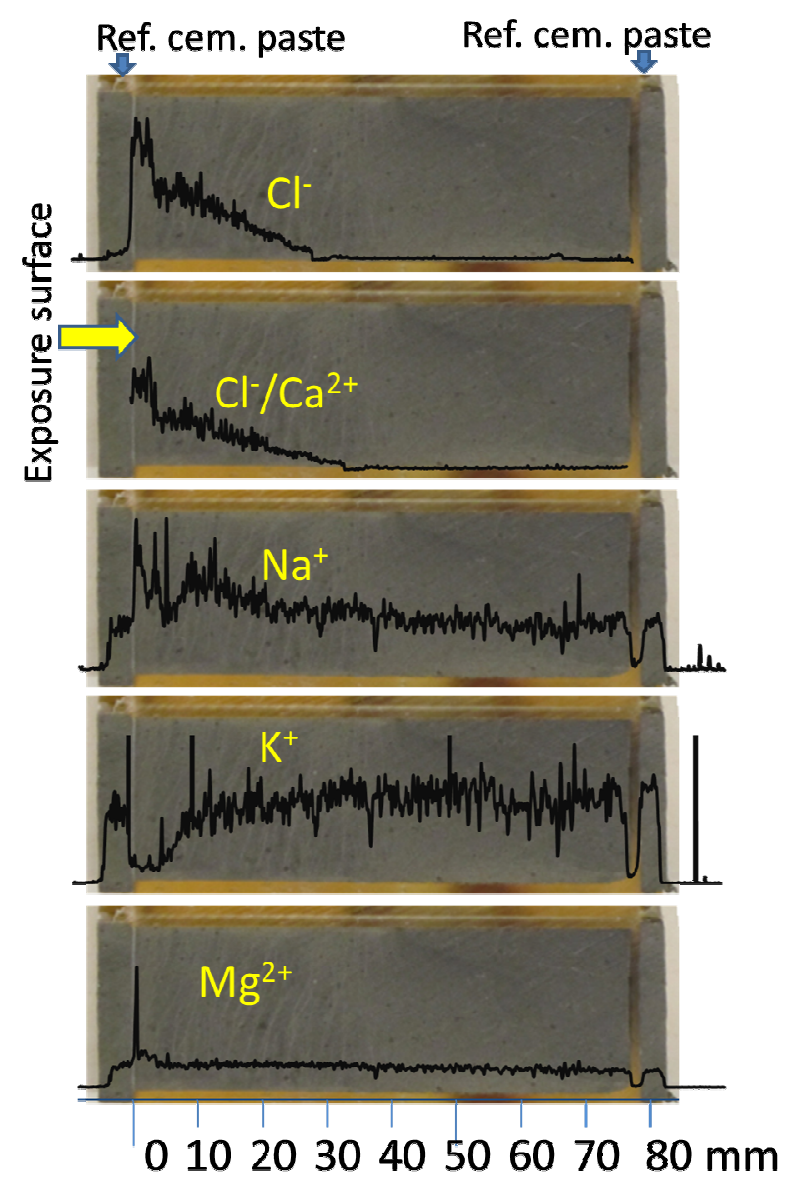

Figure 8. LA-ICP-MS results regarding qualitative chemical analysis of feild immersion test

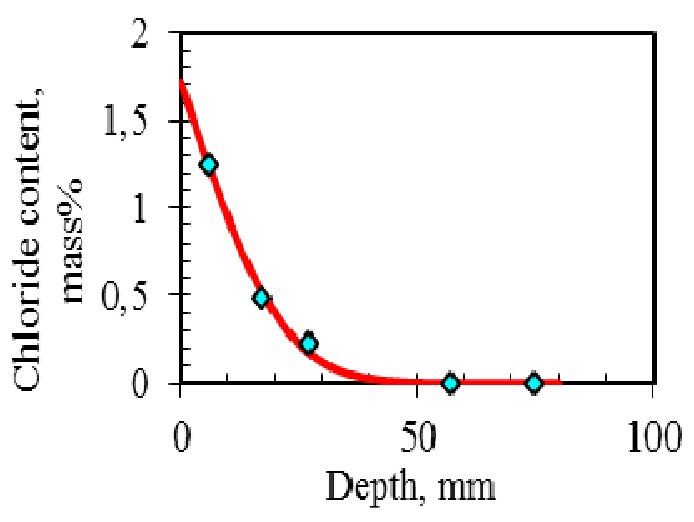

Figure 9. Curve fitting results

\section{CONCLUSIONS}

Natural diffusion cell and field immersion tests are performed. The results concerning the ions of interest being Chloride, Sodium and lithium shows:

- Diffusion coefficient of sodium and lithium ions is lower than chloride ions by an order of magnitude

- The diffusion coefficient value depends on the concentration of ions in the upstream cell

- The diffusion coefficient value is dependent on the ionic size and the radius of water field around the ion. Because as much as more water field around the 
ions the harder it gets for them to diffuse and the diffusion coefficient would decrease

\section{REFERENCE}

Abbas, Z., S.Nordholm, \& E.Ahlberg. (2009) Monte Carlo simulations of salt solutions: Exploring the validity of primitive models. J. Phys Chem B. 113, 5905-5916.

Clifton, J. (1991). Predicting the remaining service life of concrete, NISTIR-4712, U.S. Department of Commerce, National Institute of Standards and Technology, Gaithersburg, USA.

Crank, J. (1975). The mathematics of diffusion. Oxford: Clarendon press.

Fagerlund, G. (1983). Predicting the service life of concrete structures. In Proc. Engineering Foundation Conference on Characterization and Performance Prediction of Cement and Concrete, United Engineering Trustees, Inc., New York.

Page, C.L. \& Vennesland, Ø. (1983). Pore solution composition and chloride binding capacity of silica-fume cement pastes. J. Materials and Structures, 16, 19-25.

Pommersheim, J. \& Clifton, J. (1985). Prediction of concrete service-life. J. Materials \& Structures, 18 (1), 21-30.

Samson, E., Marchand, J., Robert, J.L. \& Bournazel, J.P. (1999a). Modeling the mechanisms of ion diffusion in porous media. J. Intl Journal for Numerical Methods in Engineering, 46 (1999) 20432060.

Samson, E., Lemaire, G., Marchand, J. \& Beaudoin, J.J. (1999b). Modeling chemical activity effects in strong ionic solutions. J. Computational Materials Science, 15, 285-294.

Tang L. (1996a). Chloride Transport in Concrete Measurement and prediction. Doctoral thesis, Publication P-96:6, Dept. of Building Materials, Chalmers Universities of Technology, Gothenburg, Sweden.

Tang L. (1999). Concentration dependence of diffusion and migration of chloride ions - Parts 1 \& II. J. Cement and Concrete Research. 29 (9)1463-1474.

Tang, L. \& Nilsson, L-O. (1994). A numerical method for prediction of chloride penetration into concrete structures. presented at the NATO/RILEM Workshop, St. Rémy-lès-Chevreuse 10-13 July 1994, and published in The Modelling of Microstructure and its Potential for Studying Transport Properties and Durability, (ed.) H. Jennings et al, Kluwer Academic Publisher, 539-552.

Tang, L. \& Nilsson, L-O. (1995). Transport of ions. Chapter $9.6 \& 9.8$ in "Performance Criteria for Concrete Durability", State-of-the-art Report by RILEM Technical Committee TC 116-PCD, RILEM Report 12, (ed.) J. Kropp and H.K. Hilsdorf, Chapman \& Hall, 1995.
Tang, L. \& Nilsson, L-O. (1996). Service life prediction for concrete structures under seawater by numerical approach. In Proc. 7th International Conference on the Durability of Building Materials and Components, May 19-23, 1996, Stockholm, E \& FN Spon, pp.97-106, 1996.

Truc, O. (2000). Prediction of chloride penetration into saturated concrete - Multi-species approach. PhD Thesis, Dept of Building Materials, Chalmers University of Technology (also INSA, Toulouse).

Truc, O., Ollivier J.P. \& Nilsson, L-O. (2000). Numerical simulation of multi-species diffusion. Materials and Structures, 33 (122) 566-573. 